\title{
KEBIJAKAN PENCEGAHAN TINDAK PIDANA TERORISME MELALUIKONTRA RADIKALISASI DI KABUPATEN JEMBER
}

Oleh:

\author{
Dian Eko Timuriyono \\ Email: dian_ekotimuriyono@yahoo.com
}

Kepolisian Resor Jember

\begin{abstract}
Abstrak
Selain menjadi tugas dari aparat Kepolisian, penanggulangan paham radikalisme juga harus terdapat unsur dukungan dari pemerintah daerah di Kabupaten Jember melalui kebijakan hukum pidananya.Kedua hal tersebut diatas harus terdapat sinkronisasi lembaga agar upaya penanggulangan paham radikalisme dapat dilaksanakan dengan baik.Metode penelitian ini menggunakan metode penelitian normatif melalui pendekatan perundang-undangan dan pendekatan konseptual. Hasil penelitian ini yang pertama adalah terdapat suatu kemudahan yang diperoleh dalam melaksanakan upaya penanggulangan paham radikalisme, yaitu dengan cara atau metode kontra radikalisasi yang dilakukan oleh kepolisan dan didukung oleh seluruh lembaga pemerintahan di Kabupaten Jember serta lapisan masyarakat. Kedua, pada praktiknya antara proses kontra radikalisasi tersebut berjalan, masyarakat masih mengharapkan adanya suatu proses penangkapan sampai tahapan pemidanaan terhadap pelaku terorisme sebagai bentuk dari nyatanya sebuah perlindungan hukum terhadap masyarakat Kabupaten Jember dan sekitarnya.
\end{abstract}

Kata Kunci: Penanggulangan, Kontra Radikalisasi, Kontra Narasi, Kebijakan Pemerintah.

\begin{abstract}
In addition to overcoming efforts is one of the tasks of the police, the prevention of radicalism must also have an element of support from the regional government in Jember Regency through its criminal law policy. Both of the above must be synchronized institutions so that efforts to tackle radicalism can be implemented properly. This research method uses a normative research method through the statutory approach and conceptual approach. The first result of this research is that there is an ease that is obtained in carrying out efforts to overcome the understanding of radicalism, namely by means of or counter-radicalization methods carried out by the police and supported by all government agencies in Jember Regency and the layers of society. Secondly, in practice between the counter-radicalization processes, the community still expects a process of arrest up to the stage of criminal prosecution of perpetrators of terrorism as a manifestation of a legal protection for the people of Jember Regency and its surroundings.
\end{abstract}

Keywords: Countermeasures, Counter Radicalization, Counter Narrative, Government Policy. 


\section{PENDAHULUAN}

\subsection{Latar Belakang}

Terorisme dapat didefinisikan sebagai suatu cara untuk mencapai tujuan tertentu dengan menggunakan kekerasan guna menimbulkan rasa takut dan korban sebanyakbanyaknya secara tidak beraturan. ${ }^{1}$ Sedangkan radikalisasi merupakan suatu paham yang menghendaki adanya perubahan, pergantian, dan penjebolan terhadap suatu sistem masyarakat yang tidak sesuai dengan apa yang mereka inginkan (kaum radikal). Radikalisasi menginginkan adanya perubahan secara total terhadap suatu kondisi atau semua aspek kehidupan dalam masyarakat. Sikap esktrem ini berkembangbiak di tengah-tengah panggung yang sedang dilanda kemiskinan, kesenjangan sosial, atau ketidakadilan. ${ }^{2}$

Sikap radikal merupakan respon terhadap kegagalan atau tatanan sosial politik yang ada. Kelompok pelaku kekerasan berupaya agar ideologi mereka menjadi satu-satunya alternatif yang dapat menggantikan tatanan sosial yang menurut mereka sudah tidak sepaham dengan apa yang mereka pelajari. Harapannya adalah dapat menyelesaikan permasalahan sosial dari struktur yang menyimpang dari nilai-

1.Obsatar Sinaga, Prayitno Ramelan, Ian Montratama, Terorisme Kanan Indonesia, Dinamika dan Penanggulangannya,Elex Media komputindo: Jakarta: 2018. hlm. 11.

${ }^{2}$.Zuly Qodir, Radikalisasi Agama di Indonesia, Pustaka Pelajar: Yogyakarta: 2014.hlm. 117. nilai agama.Secara internal agama, fenomena kekerasan agama bisa terjadi karena merupakan respons terhadap penyimpangan ajaran agama yang dilakukan oleh sekelompok orang. Oleh karena itu, jalan kekerasan harus dilakukan dalam rangka melakukan pemurnian kembali agama yang telah terasuki penyakit tahayul, bid'ah dan khurafat. ${ }^{3}$

Isu mengenai radikalisasi merupakan tantangan bagi masyarakat. Isu ini sebenarnya sudah lama menjadi perbincangan di permukaan wacana internasional. Banyak label-label yang diberikan oleh kalangan luar seperti Eropa Barat dan Amerika Serikat untuk menyebut gerakan radikal, contohnya kelompok garis keras, ekstremis, militan, fundamentalisme sampai terorisme. ${ }^{4}$

Menurut Ketua Pengurus Besar Nahdatul Ulama (PBNU) Ahmad Bagja, radikalisasi muncul karena ketidakadilan yang terjadi di dalam masyarakat, Kondisi tersebut bisa saja disebabkan oleh negara maupun kelompok lain yang berbeda paham juga keyakinan ${ }^{5}$. Tak jarang radikalisasi menjadi pilihan untuk menyelesaikan masalah. Namun sebagian kalangan lainnya menentang radikalisasi dalam bentuk apa-

${ }^{3}$.Agus Purnomo, Ideologi Kekerasan; Argumentasi Teologis-Sosial Radikalisasi Islam, Pustaka Pelajar: Yogyakarta, 2009.hlm. 36.

${ }^{4}$.Syaiful Arif, Islam Pancasila dan Deradikalisasi, Meneguhkan Nilai Keindonesiaan,PT Elex Media Komputindo: Jakarta, 2018. hlm. 204.

5.Agus Purnomo, Ibid.hlm. 37. 
pun sebab mereka meyakini bahwa radikalisasi justru tak menyelesaikan apapun, bahkan akan menjadikan citra agama tertentu sebagai agama yang tidak toleran dan sarat kekerasan. ${ }^{6}$

Di Indonesia, penyebaran paham radikal mulai meluas di semua kalangan terutama kalangan muda hingga masuk ke lingkungan pendidikan seperti sekolah dasar dan perguruan tinggi. Inti dari tindakan radikalisasi adalah sikap dan tindakan seseorang atau kelompok tertentu yang menggunakan cara-cara kekerasan dalam mengusung perubahan yang diinginkan dalam tempo singkat dan secara drastis serta bertentangan dengan sistem sosial. Radikalisasi sering dikaitkan dengan terorisme karena kelompok radikal dapat melakukan cara apapun agar keinginannya tercapai, termasuk meneror pihak yang tidak sepaham dengan mereka.

Terkait dengan penyebaran paham radikalisasi diperlukan perangkat hukum yang mengatur tentang tindak pidana terorisme. Menyadari hal ini dan lebih didasarkan pada peraturan yang ada saat ini yaitu Kitab Undang-Undang Hukum Pidana (KUHP), akhirnya pemerintah menyusun Peraturan Pemerintah Pengganti UndangUndang (Perpu) Nomor 1 Tahun 2002, yang pada tanggal 4 April 2003 disahkan

\footnotetext{
${ }^{6}$.Irfan Idris, Deradikalisasi, Kebijakan, Strategi dan Program Penanggulangan Terorisme, Cahaya Insani: Yogyakarta, 2018. hlm. 23.
}

menjadi Undang-Undang dengan Nomor 15 Tahun 2003 tentang Pemberantasan Tindak Terorisme (selanjutnya disebut dengan UU Terorisme).

Terorisme merupakan kejahatan terhadap kemanusiaan dan peradaban manusia serta merupakan sebuah ancaman serius terhadap kemanusiaan dan peradaban manusia serta merupakan sebuah ancaman serius terhadap keutuhan dan kedaulatan suatu Negara. ${ }^{7}$ Tindakan teror pada dasarnya memuat empat macam kriteria yakni target, tujuan, motivasi dan legitimasi dari aksi terorisme. Maka secara sederhana aksi-aksi terorisme dilatarbelakangi oleh motif-motif tertentu seperti motif ekonomi, motif balas dendam dan motif-motif berdasarkan aliran kepercayaan tertentu.Patut disadari bahwa terorisme bukan suatu ideologi atau nilainilai tertentu dalam ajaran agama.Ia sekedar strategi, instrumen atau alat untuk mencapai tujuan.

Terorisme sebagai suatu fenomena kehidupan, tidak dapat begitu saja ditanggulangi dengan kebijakan penal.Hal ini karena terorisme erat kaitannya dengan kepercayaan/ideologi latar belakang pemahaman politik dan pemaknaan atas ketidakadilan sosio-ekonomik baik lokal maupun internasional. Perlu sebuah pendekatan kebijakan kriminal secara integral dalam arti penal maupun nonpenal sekaligus.Terlebih

${ }^{7}$.Syaiful Arif, Ibid. hlm. 166. 
jaringan teroris saat ini telah terhubung satu sama lain, baik lokal ataupun internasional. Oleh karena itu, pemberantasaan korupsi harus merefleksikan upaya secara komprehensif dengan pendekatan multiagency, multi internasional dan multi nasional, sehingga perlu ditetapkan suatu strategi nasional dalam rangka perang melawan terorisme. $^{8}$

Jember sebagai salah satu kota pendidikan juga rentan menjadi salah satu tempat tumbuhnya paham-paham radikal yang berujung pada aksi teror. Adanya 2 (dua) narapidana terorisme (napiter) yang saat ini sedang menjalani hukuman di Lapas Jember menjadi salah satu faktor potensial tumbuhnya paham radikal. Keberadaan napiter tersebut memberikan dampak buruk secara langsung maupun tidak langsung bagi masyarakat Jember. Secara langsung contohnya bahwa narapidana lain yang berada satu kamar maupun berdekatan dengan kamar kedua napiter tersebut saat ini berpotensi terpapar paham radikal, sedangkan secara tidak langsung dapat dicontohkan bahwa dengan adanya napiter tersebut kemudian membawa serta keluarganya turut datang dan tinggal di wilayah kabupaten Jember yang kemudian perlahan-lahan juga memberikan pengaruh penyebaran paham radikal terhadap para

\footnotetext{
${ }^{8}$. Adjie S, Terorisme, Pustaka Sinar Harapan:
} Jakarta, 2005. hlm. 44. tetangga yang ada di sekitar lingkungan tempat tinggal mereka.

Berdasarkan latar belakang tersebut diatas perlu adanya kebijakan dari pemerintah Kabupaten Jember untuk lebih memperhatikan adanya indikasi-indikasi terjadinya aksi terorisme dari adanya penyebaran paham radikalisasme karena pada faktanya negara hanya mengatur pidana tentang terorisme melalui UU Terorisme, namun belum ada regulasi yang berpihak terhadap masyarakat tentang penyebaran paham radikalisme itu sendiri. ${ }^{9}$

\subsection{Rumusan Masalah}

Oleh karena itu, dalam penelitian ini penulis akan memfokuskan pada kajiannya yaitu, Bagaimanakah Kabupaten Jember mengklasifikasi kontra radikalisasi di Kabupaten Jember, mengingat konsepsi kontra radikalisasi dilakukan melalui kontra narasi, kontra propaganda, dan/atau kontra ideologi dalam melaksanakan kontra radikalisasi yang efektif dan efisien. Selain itu, pertanyaan yang kedua adalah, Seperti apa kebijakan penal yangideal sehingga dapatdi lakukan oleh Pemerintah Kabupaten Jember dalam pencegahan tindak pidana terorisme.

\footnotetext{
${ }^{9}$.Solahudin, Jihadisme di Indonesia, Komunitas Bambu: Jakarta: 2011.hlm. 63.
} 


\section{METODE PENELITIAN}

Penelitian ini merupakan penelitian hukum normatif, yaitu mengkaji peraturan perundang-undangan yang berlaku dan sifatnya yang normatif sehingga tipe kajiannya adalah ajaran hukum murni yang mengkaji law as it is written in the books. Tipe penelitian yuridis normatif dilakukan dengan mengkaji berbagai macam aturan hukum yang bersifat formal seperti undangundang, literatur-literatur yang bersifat konsep teoritis yang kemudian dihubungkan dengan permasalahan yang menjadi pokok pembahasan. ${ }^{10}$ Menurut Soerjono Soekanto dan Sri Maudji, penelitian hukum normatif disebut juga dengan istilah penelitian kepustakaan karena dalam penelitian hukum normatif dilakukan dengan cara meneliti bahan-bahan pustaka atau data sekunder saja, yang mencakup penelitian terhadap asas-asas hukum, penelitian terhadap sistematik hukum, penelitian terhadap taraf sinkronisasi vertikal dan horisontal, perbandingan hukum dan sejarah hukum. ${ }^{11}$

Pendekatan yang digunakan dalam penelitian ini meliputi pendekatan perundang-undangan, konseptual, dan kasus. Pen-dekatan perundang-undangan dilakukan dengan menelaah semua undangundang dan regulasi yang bersangkut paut

\footnotetext{
${ }^{10}$. Ibid.hlm.194

${ }^{11}$.Dyah Ochtorina Susanti dan A'an Efendi, Penelitian Hukum (Legal Research), Sinar Grafika: Jakarta, 2014. hlm. 19.
}

dengan isu hukum yang diketengah-kan. ${ }^{12}$ Pendekatan konseptual dilakukan manakala peneliti tidak beranjak dari aturan hukum yang ada. Hal itu dilakukan karena memang belum ada atau tidak ada aturan hukum untuk masalah yang dihadapi.

\section{PEMBAHASAN}

\subsection{Pelaksanaan Kontra Radikalisasi di Kabupaten Jember}

a. Radikalisme, Terorisme, dan Kontra Radikalisasi

Terorisme akan selalu tegak lurus dengan perkembangan paham radikalisme. Paham ini ibarat lahan tempat lahirnya tindakan-tindakan teror di suatu wilayah. Jika lahan tersebut gersang maka terorisme akan sulit berkembang, sebaliknya jika lahan tersebut subur maka terorisme akan sangat cepat berkembang karena terdukung oleh situasi lingkungan sekitarnya. Lahan subur tersebut menurut Hendro Priyono adalah masyarakat yang dicemari oleh paham fundamentalisme ekstrem atau radikalisme keagamaan. ${ }^{13}$

Pada umumnya, radikalisasi yang mengatasnamakan agama muncul dari pemahaman agama yang tertutup dan tekstual hingga merasa hanya kelompoknya yang paling benar. Sedangkan pemahaman ter-

\footnotetext{
${ }^{12}$. Ibid. hlm. 110.

${ }^{13}$.Hendro Priyono, Terorisme: Fundamentalis Kristen, Yahudi dan Islam, Buku Kompas: Jakarta, 2009. hlm. 13.
} 
hadap kelompok lain dianggap sesat atau tidak benar dan/atau justru kelompok lain dianggap sudah kafir sehingga menganggap bahwa golongan tersebut berhak untuk diperangi dengan kekerasan.

Dalam perspektif Islam, kemunculan paham radikalisme diawali oleh ketidakmampuan sebagian Muslim dalam mengintegrasikan sistem kehidupan berbangsa modern. Ketidaksetujuan dan ketidakpuasan yang disebabkan oleh kegagalan mereka dalam mengintegrasikan diri menempatkan mereka sebagai pihak yang kalah, yang mereka pahami sebagai hilangnya dimensi spiritual dalam kehidupan mereka. $^{14}$

Kaum radikal adalah orang-orang yang menolak sistem kehidupan berbangsa modern karena dianggap tidak sesuai dengan nilai-nilai Islam. Hal ini disebabkan karena ketidakmampuan mereka dalam mengintegrasikan nilai, ajaran dan konsep Islam ke dalam struktur masyarakat modern, baik pada ranah pendidikan, keluarga, ekonomi hingga politik.

Selain itu, ada beberapa faktor lain yang dapat memotivasi seseorang mengembangkan pahamnya sehingga bermuara pada perilaku teror.Faktor tersebut diantaranya:

1. Faktor kondisi atau keadaan negara yang mengalami krisis ekonomi atau kemiskinan sehingga penganut paham radikal

\footnotetext{
${ }^{14}$.Syaiful Arif, Ibid. hlm. 173.
}

merasa kecewa dengan sistem pemerintahan yang ada dan meluapkannya dengan aksi kekerasan dengan melakukan terorisme. $^{15}$

2. Faktor internasional, yakni pengaruh lingkungan dari luar negeri yang memberikan dukungan dengan menumbuhkan rasa sentimen keagaman seperti ketidakadilan global, politik yang arogan dan imperialisme negara modern.

3. Faktor budaya juga sangat berketerkaitan dengan adanya pemberian pemahaman yang sempit dan pemberian penafsiran kitab suci yang kurang luas. ${ }^{16}$

Paham radikalisme selalu menjadi ancaman serius bagi keberlangsungan kehidupan berbangsa dan bernegara. Penyebarannya yang begitu cepat menjadi tugas penting bagi pemerintah khususnya penegak hukum untuk memberantas paham radikalisme khususnya pencegahan penyebaran paham tersebut. Terlebih lagi, perkembangan teknologi membuat penyebaran radikalisme lebih luas dan lebih tidak terkontrol sehingga perlu dilakukan pemberantasan dan yang paling terpenting adalah dilakukannya suatu tindakan pencegahan.

Pencegahan penyebaran paham radikalisme dapat dilakukan dengan beberapa

\footnotetext{
${ }^{15}$.Satria,Anatomi Hukum Pidana Khusus, UII Press: Yogyakarta, 2014.hlm. 113.

${ }^{16}$.Ibid. hlm. 114.
} 
cara, salah satunya melalui kontra radikalisasi. Kontra radikalisasi sendiri terdiri dari beberapa hal, diantaranya adalah kontra narasi, kontra propaganda, dan kontra ideologi. ${ }^{17}$

\section{Kontra Narasi Radikalisasi}

Kontra narasi radikalisasi adalah menyebarkan nilai-nilai damai kepada seluruh lapisan tanpa memandang kelompok, ideologi, atau batas-batas lainnya, dengan tujuan menyampaikan pesan kebaikan, untuk mencegah perkembangan paham radikalisme dikalangan masyarakat untuk meminimalisir penyebaran paham radikalisme. Hal ini dilakukan tidak hanya terhadap orang yang rentan terpapar paham radikal, tetapi juga kepada orang-orang yang yang telah mempunyai mindset paham radikalisme atau mereka yang sudah termasuk dalam golongan penganut paham radikal. ${ }^{18}$ Contohnya adalah menyebarkan narasinarasi kepada masyarakat dalam berbagai bentuk kegiatan seperti seminar, kajian publik, diskusi, penyebaran slogan dan pamflet menolak paham radikalisme.

\footnotetext{
${ }^{17}$.Sunardi, Klausula Attentat Dalam Kaitannya Dengan Ekstradisi Pelaku Tindak Pidana Terorisme, Disertasi,Program Pascasarjana Fakultas Hukum Universitas Brawijaya, Malang, 2009.hlm. 73.

18 ."Skenario kontra narasi untuk mencegah teror", http://www.neraca.co.id,diakses tanggal 24 September 2019.
}

2. Kontra Propaganda Radikalisasi

Menurut Kamus Besar Bahasa Indonesia (KBBI), propaganda adalah penerangan (paham, pendapat, dan sebagainya) yang benar atau salah yang dikembangkan dengan tujuan menyakinkan orang agar menganut satu aliran, sikap, atau arah tindakan tertentu. ${ }^{19}$ Maka yang dimaksud dengan kontra propaganda radikalisasi adalah upaya untuk menangkal dan melawan potensi teror yangekstrem dan biasa dipropagandakan oleh terorisme melalui media elektronik, terutama internet dengan cara menampilkan audio maupun visualisasi tentang dampak dan bahaya yang ditimbulkan oleh aksi teror. Contoh kontra propaganda yang dapat dilakukan membuat konten di media sosial tentang dampak atau akibat dari aksi teror yang menimbulkan banyak korban jiwa sehingga masyarakat menjadi antipati terhadap pelaku teror maupun pendukung-pendukungnya.

3. Kontra Ideologi Radikalisasi

Kontra ideologi radikalisasi adalah upaya pencegahan terhadap masuknya bahaya paham radikalisme dengan cara memberikan sosialisasi dengan melibatkan mantan narapidana terorisme yang telah sadar dari pengaruh paham radikal dan menyatakan diri sebagai bagian dari masyarakat yang mengakui ideologi

\footnotetext{
${ }^{19}$ Www.kbbi.web.id, diakses pada tanggal 20Oktober 2019.
} 
Pancasila, UUD 1945 dan keutuhan NKRI. ${ }^{20}$ Contohnya adalah pemberian seminar dengan menghadirkan narasumber mantan narapidana terorisme untuk memberikan gambaran seputar konflik batin yang dirasakan oleh para pelaku terorisme saat melakukan aksinya.

b. Perkembangan Terorisme di Kabupaten Jember

Kasus penyebaran paham radikalisme dengan adanya tindakan terorisme yang terjadi di Kabupaten Jember adalah bermula pada tahun 2010. Polres Jember mengamankan seseorang berusia sekitar 41 tahun dan ditemukan beberapa buku yang ditulis oleh tiga serangkai pelaku Bom Bali I ditempat kediamannya. Selanjutnya pada tahun 2012 terdapat 2 (dua) pelaku yang ditembak mati oleh Tim Densus 88 Anti Teror di Bali, yang mengejutkan adalah kedua pelaku tersebut merupakan warga di kabupaten Jember.

Contoh lain berkaitan dengan terorisme di kabupaten Jember dapat dilihat dengan adanya 2 narapidana terorisme berasal dari Rutan Kelapa Dua Depok Jawa Barat yang dipindah ke Lapas Jember, dikarenakan Lapas Kelapa Dua tidak cukup menampung napiter yang akan terus diprediksikan bertambah jumlahnya. Hal itu membawa serta merta keluarga mereka

\footnotetext{
20 "BNPT sebut kontra ideologi efektif tanggulangi ancaman terorisme https://m.wartaekonomi.co.id, diakses tanggal 02 Oktober 2019.
}

untuk datang dan berdomisili di kabupaten Jember. Fasilitas dan kebutuhan sehari-hari keluarga napiter tersebut dibantu oleh ketua JAD (Jamaah Ansharut Daulah) Jember berinisial WS yang berprofesi sebagai guru mengaji dan ilmu agama di salah satu yayasan swasta di kabupaten Jember.

Aktivitas keluarga napiter setiap harinya ikut membantu mengajar di yayasan WS yang semakin hari semakin berkembang, termasuk orang-orang disekitar tempat tinggal WS yang lambat laun juga ikut terpapar paham radikalisme. Sedangkan dua orang napiter yang dititipkan ke Lapas Jember juga turut berkontribusi dalam menyebarkan paham radikalisme didalam tahanan. Hal tersebut terbukti dengan adanya narapidana lain yang terkontaminasi dengan paham yang mereka yakini tersebut. Seperti contoh, narapidana tersebut tidak mau memakan jatah makanan yang diberikan oleh Lapas Jember kepada mereka karena dianggap haram, narapidana tersebut juga merubah penampilan dengan cara berpakaian sesuai ajaran paham radikalisme mereka.

Selain kasus tersebut, berdasarkan pemberitaan di media-media sosial, kasus terorisme lainnya jugaakan berpotensi terjadi di kabupaten Jember yakni dengan adanya penggeledahan rumah seorang warga Jember karena diduga terlibat kasus terorisme, rumah tersebut digeledah oleh tim densus 88 antiteror yang terdiri dari 15 
petugas. Petugas melakukan penggeledahan di rumah pria berinisial $\mathrm{AR}$, di perumahan Istana Tegal Besar Cluster Kutai, kecamatan Kaliwates. Pada hari Kamis tanggal 2 Agustus 2018, sekitar pukul 3 sore, yang disaksikan oleh ketua Rukun Tetangga (RT) setempat, pada saat itu dirumah terdapat istri dan 3 (tiga) orang anaknya. AR terindikasi terlibat dalam kasus peledakan bom yang berada di Surabaya dan Kuningan pada saat itu, dalam pengeledahan tersebut petugas menemukan beberapa barang bukti berupa rekaman percakapan telepon, bukubuku tentang idelogi khilafah Islam, bahanbahan kimia yang diindikasi sebagai salah satu bahan pembuatan bom, sehingga tidak menutup kemungkinan bahwa AR juga akan merencanakan pengeboman di wilayah Kabupaten Jember.

Kasus hilangnya mahasiswi salah satu universitas di Kabupaten Jember juga menambah daftar perkembangan paham radikalisme yang terjadi, yang kemudian diketahui bahwa mahasiswi tersebut ternyata ikut dan masuk dalam aliran JAD dengan mengikuti pengajian-pengajian dan pelatihan agama yang diselenggarakan oleh JAD Jember. Bahkan tidak sedikit para akademisi dan dosen yang turut serta bergabung dalam aliran JAD tersebut, berperan sebagai pencuci otak (brain wash) untuk menyebarkan paham radikalisme dikalangan pelajar dan mahasiswa, sehingga dapat disimpulkan bahwa kabupaten Jem- ber saat ini telah darurat terhadap penyebaran paham radikalisme.

1. Pelaksanaan Kontra Radikalisasi di Kabupaten Jember

Kontra radikalisasi adalah pemberian pemahaman dengan memberikan benteng kepada orang-orang yang belum terpapar atau rentan terkontaminasi paham ekstrem tersebut. Kontra radikal ini bertujuan untuk mencegah orang-orang yang belum kenal terhadap paham radikal agar tidak terpengaruh apabila suatu saat ada yang menghasutnya untuk mengikuti paham tersebut. Sebaliknya, deradikalisasi adalah pemberian pemahaman kepada mereka yang telah terlanjur memahami dan bahkan mengikuti paham radikal, dan perlu ada pendekatan tersendiri untuk merubah pandangan mereka terhadap paham radikal. ${ }^{21}$

Kabupaten Jember sendiri telah melakukan langkah-langkah dalam pencegahan penyebaran paham radikalisme melalui kontra radikalisasi. Pertama, upaya kontra radikalisasioleh Badan Nasional Penanggulangan Terorisme (BNPT).Pada tahun 2015 BNPT mengajak seluruh tokoh ulama di Kabupaten Jember untuk mencegah meluasnya paham radikalisme dan terorisme. Sebagai bentuk pencegahan paham radikalisme dan terorisme, ratusan kyai dari berbagai membubuhkan tanda tangan mereka

21. Irfan Idris, Deradikalisasi, Kebijakan, Strategi dan Program Penanggulangan Terorisme, Cahaya Insani: Yogyakarta, 2018.hlm. 98. 
di atas kain putih yang direntangkan sepanjang 10 meter. Kontra radikalisasi tersebut dilakukan dengan melibatkan masyarakat umum, pondok pesantren, alim ulama, dan tokoh masyarakat. ${ }^{22}$

Kedua, upaya kontra radikalisasi oleh Kepolisian Resor Jember (Polres Jember). Pada tanggal 8 Januari 2019, Polres Jember bekerjasama dengan Universitas Jember mengadakan Seminar Kebangsaan dengan tema Revitalisasi Nilai Peradaban Manusia Demi Terwujudnya Pemilu Aman dan Damai Serta NKRI yang Sejahtera. Mengingat bahwa betapa polemik pemilu 2019 yang pada saat itu terjadi di Indonesia, penyebaran ujaran kebencian, berita hoax, serta keadaan-keadaan lain yang dapat memecahkan persatuan masyarakat Indonesia, karena dengan kondisi Indonesia yang politiknya sangat terguncang dengan mudah para oknum tertentu untuk masuk dan menyebarkan paham-paham radikal dikalangan masyarakat. Sehingga dibuatlah seminar kebangsaan tersebut dengan tujuan, mempererat persatuan bangsa Indonesia, agar Indonesia tetap damai walaupun dalam keadaan poltik yang sedang bergejolak akibat oknum-oknum yang tidak bertanggung jawab yang ingin memecahkan persatuan bangsa dengan tujuan tertentu.

\footnotetext{
${ }^{22}$."BNPT gandeng kyai seluruh jember untuk cegah radikalisasi, https://regional.kompas.com, diakses tanggal 2 Agustus 2019.
}

Selain itu, Polres Jember Sub Satuan Kerja fungsi Intelkam yang di dalamnya memiliki unit keamanan khusus yang mempunyai tugas pokok melakukan penyelidikan, maping, profiling, dan deteksi terhadap individu maupun kelompok yang terindikasi berafiliasi dengan paham radikal ataupun teroris serta bekerja sama dengan instansi terkait melakukan upaya pencegahan terhadap masuknya paham radikalisme di kabupaten Jember ${ }^{23}$.

Ketiga, Badan Kesatuan Bangsa dan Politik (Bakesbangpol) Kabupaten Jember sebagai lembaga yang bertanggungjawab menyusun dan melaksanakan kebijakan daerah di bidang kesatuan bangsa dan politik telah melakukan serangkaian upaya pencegahan terhadap bahaya masuknya paham radikalisme di kabupaten Jember dengan cara antara lain: ${ }^{24}$

a. Pembentukan Kominda (Komunitas Intelijen Daerah) yang terdiri dari unit deteksi Bakesbangpol kabupaten Jember, unit Intelijen Kejaksaan Negeri Jember, unit Intelijen Satuan TNI yang ada di kabupaten Jember, unit deteksi Satuan Polisi Pamong Praja kabupaten Jember, dan Satuan Intelijen Keamanan Polres Jember yang memiliki fungsi sebagai

\footnotetext{
${ }^{23}$.Wawancara denganAgus Setiyono Hari, pada tanggal 25 September 2019 di Kantor Polres Jember.

${ }^{24}$.Wawancara dengan Bambang Hariyono, Kepala Bakesbangpol kabupaten Jember pada tanggal 26 September 2019 di Kantor Pemerintah Kabupaten Jember.
} 
sarana komunikasi dan pertukaran informasi berkaitan dengan segala isu yang berkaitan dengan ideologi, politik, ekonomi, sosial budaya, hukum, dan keamanan di kabupaten Jember termasuk tentang potensi muncul dan berkembangnya paham radikalisme.

b. Memberikan bimbingan dan penyuluhan terhadap masyarakat pedalaman, pesantren-pesantren, organisasi kepemudaan dan kemasyarakatan tentang bahaya paham radikalisme.

c. Pemberian materi tentang wawasan kebangsaan dan bahaya paham radikalisme serta narkoba terhadap generasi muda khususnya pelajar dan mahasiswa agar dapat diimplementasikan dalam kehidupan sehari-hari.

Keempat, Majelis Ulama Indonesia (MUI) Kabupaten Jember melalui kewenangannya memberikan saran dan masukan kepada pemerintah daerah kabupaten Jember, Polres Jember, Kodim 0824 Jember dan Kejaksaan Negeri Jember untuk lebih proaktif melakukan pengawasan terhadap gejala munculnya paham radikalisme di beberapa daerah tertentu di wilayah kabupaten Jember yang ditandai dengan adanya kelompok-kelompok baru yang mengadopsi budaya diluar nilai-nilai ideologi Pancasila yang berpotensi dapat menganggu ketentraman masyarakat dilingkungan sekitar munculnya kelompok tersebut, selain itu MUI senantiasa berperan aktif memberikan dakwah-dakwah dikalangan masyarakat tentang nilai-nilai keislaman yang benar sehingga diharapkan dapat menjadi daya tangkal bagi masyarakat terhadap potensi perkembangnya paham radikalisme. ${ }^{25}$

Berdasarkan hasil wawancara dengan kedua narasumber diatas, dapat ditarik kesimpulan bahwa upaya-upaya pencegahan dan penanggulangan terhadap bahaya masuknya paham radikalisme di Kabupaten Jember lebih dominan dilakukan dengan cara kontra radikalisasi dimana stakeholder terkait lebih mengedepankan pemahaman terhadap potensi bahaya radikal kepada masyarakat yang belum pernah terpapar atau rentan terkontaminasi paham radikalisme. Kegiatan kontra radikalisasi tersebut lebih cenderung menggunakan metode kontra narasi, yaitu menyebarkan nilai-nilai damai kepada seluruh lapisan tanpa memandang kelompok, ideologi, atau batas-batas lainnya, dengan tujuan menyampaikan pesan kebaikan, untuk mencegah perkembangan paham radikalisme dikalangan masyarakat untuk meminimalisir penyebarannya. Polres Jember, Bakesbangpol dan MUI kabupaten Jember memberikan materi penyuluhan kepada berbagai elemen masyarakat tentang pen-

\footnotetext{
${ }^{25}$ Wawancara dengan Halim Subahar, pada tanggal 26 September 2019 di Kantor Majelis Ulama Indonesia cabang kabupaten Jember.
} 
tingnya memelihara keberlangsungan ideologi Pancasila dan menangkal bahaya paham radikalisme guna menjaga keutuhan NKRI.

\subsection{Kebijakan Hukum Pidana Dalam UpayaPencegahan Tindak Pidana} Terorisme di Kabupaten Jember

Tindak pidana terorisme merupakan kejahatan Internasional yang membahayakan keamanan dan perdamaian dunia serta merupakan pelanggaran berat terhadap hak asasi manusia, terutama hak untuk hidup. Rangkaian tindak pidana terorisme yang terjadi di wilayah Negara Kesatuan Republik Indonesia telah mengakibatkan hilangnya nyawa tanpa memandang korban, ketakutan masyarakat secara luas, dan kerugian harta benda sehingga berdampak luas terhadap kehidupan sosial, ekonomi, politik, dan hubungan Internasional. ${ }^{26}$ Menurut Hoefnagels, upaya penanggulangan kejahatan dapat dilakukan dengan cara: $^{27}$

1. Penerapan Hukum Pidana, dalam hal ini dapat menerapkan Pasal 354 KUHP dengan hukuman maksimal 8 Tahun baik dalam tuntutan maupun dalam putusan;

\footnotetext{
${ }^{26}$. Hery Firmansyah, Upaya Penanggulangan Tindak Pidana Terorisme di Indonesia, Mimbar Hukum, 23 (2011):385.

27. Widodo, Memerangi Cyber crime, KarakteristikMotivasi, dan Strategi Penanganannya dalam Perspketif Kriminolog, AswajaPressindo: Yogyakarta 2013. hlm. 9.
}

2. Pencegahan Tanpa Pidana, dalam hal ini dapat menngunakan penerapan hukuman maksimal pada pelaku kejahatan, maka secara tidak langsung memberikan prevensi (pencegahan) kepada public walaupun ia tidak dikenai hukuman kepada masyarakat.

3. Mempengaruhi Pandangan Masyarakat tentang Kejahatan dan Hukuman, mensosialisasikan suatu undang-undang dengan memberikan gambaran tentang bagaimana delik itu dan ancaman hukumannya.

Upaya penanggulangan kejahatan mencakup aktivitas preventif dan sekaligus berupaya untuk memperbaiki perilaku seseorang yang telah dinyatakan bersalah di lembaga pemasyarakatan juga telah dilakukan, dengan kata lain upaya penanggulangan kejahatan dapat dilakukan secara preventif dan represif. Upaya yang dilakukan dalam rangka mengurangi tindakan radikalisasi pada masyarakat Indonesia perlu dimulai dengan upaya preventif, tanpa langkah preventif yang tepat, aksi teror akan terus terjadi dalam skala yang lebih luas dan frekuensi yang lebih sering. Penanggulangan kejahatan secara preventif dilakukan untuk mencegah terjadinya atau timbulnya kejahatan yang pertama kali. Oleh karena itu pemerintah yang diwakili oleh BNPT melakukan dua strategi yang salah satunya adalah kontra radikalisasi. 
Kontra radikalisasi merupakan awal upaya yang dilakukan pemerintah untuk mengurangi serta menghilangkan benih-benih terorisme di Indonesia.

Dalam rangka mewujudkan pencegahan terhadap tindak pidana terorisme diperlukan undang-undang yang mengatur atau meregulasi tentang pemberantasan tindak pidana terorisme dapat menimbulkan implikasi hukum bagi kepentingan nasional maupun kepentingan Internasional.Oleh sebab itu Undang-Undang yang mengatur tentang pemberantasan tindak pidana terorisme perlu memperhatikan dua acuan utama dan satu acuan pelengkap yakni konvensi Internasional, resolusi serta undangundang lama. ${ }^{28}$

Pada tahun 2018 Pemerintah mengeluarkan Undang-Undang Nomor 5 Tahun 2018 tentang Perubahan atas Undang-Undang Nomor 15 Tahun 2003 Tentang Penetapan Peraturan Pemerintah Pengganti Undang-Undang Nomor 1 Tahun 2002 Tentang Pemberantasan Tindak Pidana Terorisme menjadi Undang-Undang. Sebelum dikeluarkan Undang-Undang pada tahun 2018, pada tahun 2002 pemerintah mengeluarkan Peraturan Pemerintah yang mengenai Pemberantasan Tindak Pidana Terorisme lalu pada 2003 peraturan tersebut di undang-undangkan. Pada tahun 2010 pemerintah juga mengeluarkan Perpres

\footnotetext{
${ }^{28}$.Sunardi, Ibid.hlm. 76.
}

Nomor 46 Tahun 2010 tentang pembentukan Badan Nasional Penanggulangan Terorisme (BNPT) yang pada tahun 2012 diubah dengan Perpres No. 12 Tahun 2012. Pembentukan BNPT merupakan kebijakan negara dalam melakukan terorisme di Indonesia sebagai pengembangan dari Desk Koordinasi Pemberantasan Terorisme (DKPT) yang dibuat pada tahun 2002.

Namun peraturan yang telah dikeluarkan dalam rangka memberantas terorisme belum secara lengkap dan tuntas serta aturan tersebut belum mengatur mengenai upaya preventif pemerintah dalam rangka memberantas tindak pidana terorisme sehingga, Menurut Abdul Wahid pada Rumusan Pasal 6 UU Nomor 15 Tahun 2003 tentang Pemberantasan Tindak Pidana Terorisme sangat interpretatif dan sangat elastis serta tidak jelas batasan-batasanya, sebab belum melakukan tindak pidana terorisme sudah mendapat ancaman hukuman yang berat. Jadi pasal tersebut meskipun dapat diterapkan, akan tetapi masih harus dipilah dan dipilih terhadap kasus tertentu. $^{29}$

Terkait demikian, oleh sebab itu Undang-Undang Nomor 15 Tahun 2003 dirasa kurang memberikan kepastian hukum sehingga pada tahun 2018 melalui

29. Abdul Wahid, Kejahatan Terorisme, Prespektif Agama, HAM, dan Hukum, Refika Aditama: Bandung, 2004.hlm. 77. 
Undang-Undang Nomor 5 Tahun 2018 pemerintah melakukan perubahan atas peraturan sebelumnya dan membuat regulasi yang lebih lengkap dan jelas mengenai proses pemerintah dalam pemberantasan tindak pidana terorisme serta menjelaskan upaya preventif serta represif yang harus dilakukan dalam pemberantasan terorisme. Pasal 43 huruf a dalam Undang-Undang Nomor 5 Tahun 2018 menyebutkan bahwa pemerintah wajib melakukan pencegahan tindak pidana terorisme, pemerintah juga dituntut untuk melakukan antisipasi secara terus menerus yang dilandasi dengan prinsip perlindungan hak asasi manusia dan prinsip kehati-hatian.

Oleh karena itu pencegahan yang dilakukan berupa kesiapsiagaan nasional, kontra radikalisasi dan deradikalisasi. Ketentuan ini dimaksudkan untuk efisiensi serta efektivitas dalam pencegahan tindak pidana terorisme. Kontra radikalisasi yang dimaksud dalam Pasal 43 huruf a lalu dijelaskan dalam Pasal 43 huruf c yang menyebutkan bahwa kontra radikalisasi merupakan suatu proses yang terencana, terpadu, sistematis, dan berkesinam-bungan yang dilaksanakan terhadap orang atau kelompok orang yang rentan terpapar paham radikal terorisme yang dimaksudkan untuk menghentikan penyebaran paham radikal terorisme.

Aksi terorisme di kabupaten Jember dapat dilihat dengan tertangkapnya 2 (dua) narapidana terorisme (napiter) yang saat ini sedang menjalankan hukuman di Lapas Jember, dengan keberadan napiter tersebut memberikan keresahan bagi masyarakat Jember. Seperti yang dipahami bahwa paham radikalisme biasanya diterapkan dalam lingkungan keluarga, yang menjadi kekhawatiran, bahwa keluarga napiter tersebut akan sering melakukan interaksi di wilayah Jember sehingga tidak menutup kemungkinan bahwa penyebaran paham radikal akan semakin luas di kabupaten Jember.

Kebijakan pemerintah kabupaten Jember dalam penerapan hukum pidana terhadap para pelaku tindak pidana telah melalui prosedur hukum yang telah ada, dibuktikan dengan pemindahan narapidana tindak pidana terorisme ke Lapas Kelas II A Jember dari Lapas Porong, pada tanggal 11 September 2015, berdasarkan ketentuan peraturan perundang-undangan napiter tersebut melanggar Pasal 5 Jo. Pasal 4 Undang-Undang Nomor 15 Tahun 2003 tentang Pencegahan dan Pemberantasan Tindak Pidana Terorisme, dengan vonis hakim 10 Tahun dan denda Rp. 50.000.000.00,-, subsidair 3 bulan penjara. Selain itu, pada tanggal 29 September 2015 telah dipindahkan narapidana tindak pidana terorisme ke Lapas Kelas II A Jember dari Rutan Kelapa Dua Depok Jawa Barat, yang terbukti melanggar Pasal 15 Jo. Pasal 9 Peraturan Pemerintah Nomor pengganti 
Undang-Undang Nomor 1 Tahun 2002 menjadi Undang-Undang Nomor 15 Tahun 2003 tentang Pemberantasan Terorisme, dengan vonis 5 Tahun 6 Bulan penjara.

Terkait hal tersebut, dapat dilihat bahwa pemerintah kabupaten Jember ikut serta berperan dalam pencegahan dan pemberantasan tindak pidana terorisme yang dibantu oleh segenap penegak hukum di pemerintahan kabupaten Jember. Akan tetapi hal tersebut dirasa kurang cukup dalam mencegah terjadinya penyebaran paham radikalisme yangterjadi di kalangan masyarakat umum, pondok pesantren, sekolah dasar hingga perguruan tinggi di kabupaten Jember sehingga perlu adanya kebijakan dari pemerintah kabupaten Jember untuk lebih memperhatikan adanya indikasi-indikasi terjadinya aksi terorisme dari adanya penyebaran paham radikalisme karena pada faktanya negara hanya mengatur pidana tentang terorisme melalui Undang-Undang Nomor 5 Tahun 2018 tentang Pemberantasan Tindak Pidana Terorisme, namun belum ada regulasi yang berpihak terhadap masyarakat tentang penyebaran paham radikalisme itu sendiri.

Seyogyanya pemerintah daerah lebih proaktif melakukan upaya-upaya cegah tangkal terhadap masuknya penyebaran paham radikal di kabupaten Jember, seperti halnya membuat kesepakatan bersama dalam bentuk aturan kerjasama yang didalamnya melibatkan seluruh instansi pemerintahan, kepolisian, kejaksaan dan dinas terkait serta menggandeng elemen masyarakat, juga berkoordinasi dengan tokoh agama dan akademisi guna merumuskan bahan materi yang sesuai dengan karakter masyarakat Jember sebagai sarana dalam melakukan kegiatan kontra radikalisasi dan deradikalisasi sebagai salah satu upaya pencegahan penyebaran paham radikalisme di kabupaten Jember. Dalam regulasi kerjasama pemerintah kabupaten Jember nantinya juga dijelaskan perananperanan masing-masing instansi terkait, secara terintegrasi apabila di kabupaten Jember diketahui atau ditemukan adanya praktek, gejala, dan tanda-tanda dari seseorang, kelompok, ataupun organisasi yang terindikasi menganut paham-paham radikalisme.

Seperti contoh, apabila ada sebuah yayasan yang terindikasi paham radikalisme, MUI memberikan pencerahan tentang bagaimana seharusnya ajaran Islam yang diajarkan agar tidak menyimpang dari ajaran yang telah ada sebelumnya, pihak kepolisian dan kejaksaan melakukan penyelidikan dan penyidikan terkait adanya indikasi paham radikalisme tersebut sesuai dengan porsinya masing-masing. Sedangkan kewenangan pemerintah daerah dan dinas pendidikan mendalami legalitas yayasan tersebut, dan apabila diperlukan dapat mencabut ijin atau membekukan ijin operasionalnya. Sehingga hal tersebut 
nantinya dapat dijadikan filterisasi dan diharapkan akan meminimalisir adanya penyebaran paham radikalisme di wilayah kabupaten Jember dengan melibatkan seluruh instansi dan elemen terkait.

\section{KESIMPULAN}

Pelaksanaan kontra radikalisasi di kabupaten Jember dalam mencegah dan meminimalisir adanya penyebaran paham radikalisme hingga terjadinya aksi terorisme dilakukan dengan beragam cara, mulai dari langkah kontra radikal hingga deradikalisasi. Aparat penegak hukum di kabupaten Jember menerapkan kontra narasi radikalisasi dalam mencegah penyebaranpaham radikalisme yang berkembang di kabupaten Jember karena dengan menggunakan pendekatan ini dinilai lebih mudah dan bisa diterima oleh seluruh kalangan masyarakat. Penerapan kontra narasi dengan cara menyebarkan narasi-narasi kepada masyarakat dalam berbagai bentuk kegiatan seperti seminar, kajian publik, diskusi, penyebaran slogan-slogan dan pamflet untuk menolak penyebaran paham radikalisme di tempat-tempat umum atau dalam kegiatan tertentu.

Sementara itu, vonis hukuman yang dijatuhkan kepada napiter di Lapas Jember membuktikan bahwa pemerintah kabupaten Jember telah ikut serta berperan dalam pencegahan dan pemberantasan tindak pidana terorisme yang dibantu oleh segenap penegak hukum di pemerintahan kabupaten Jember. Akan tetapi hal tersebut dirasa kurang cukup dalam mencegah terjadinya penyebaran paham radikalisme yangterjadi di kalangan masyarakat umum, pondok pesantren, sekolah dasar hingga perguruan tinggi sehingga perlu adanya regulasi kebijakan dari pemerintah kabupaten Jember untuk lebih memperhatikan adanya indikasi-indikasi penyebaran paham radikalisme. Karena pada faktanya negara hanya mengatur pidana tentang terorisme melalui Undang-Undang Nomor 5 Tahun 2018 tentang Pemberantasan Tindak Pidana Terorisme, namun belum ada regulasi yang berpihak terhadap masyarakat tentang penyebaran paham radikalisme itu sendiri. Seyogyanya pemerintah daerah membuat regulasi kebijakan yang melibatkan seluruh instansi pemerintahan, kepolisian, kejaksaan dan dinas terkait sesuai dengan karakter masyarakat Jember sebagai sarana dalam melakukan upaya pencegahan penyebaran paham radikalisme di kabupaten Jember. 


\section{DAFTAR PUSTAKA}

\section{Buku}

Abdul Wahid, Kejahatan Terorisme, Prespektif Agama, HAM, dan Hukum, Refika Aditama: Bandung, 2004.

Adjie S, Terorisme, Pustaka Sinar Harapan: Jakarta, 2005.

Agus Purnomo, Ideologi Kekerasan; Argumentasi Teologis-Sosial Radikalisasi Islam, Pustaka Pelajar: Yogyakarta, 2009.

Dyah Ochtorina Susanti dan A'an Efendi, Penelitian Hukum (Legal Research), Sinar Grafika: Jakarta, 2014.

Hendro Priyono, Terorisme: Fundamentalis Kristen, Yahudi dan Islam, Buku Kompas: Jakarta, 2009.

Irfan Idris, Deradikalisasi, Kebijakan, Strategi dan Program Penanggulangan Terorisme, Cahaya Insani: Yogyakarta, 2018.

Irfan Idris, Deradikalisasi, Kebijakan, Strategi dan Program Penanggulangan Terorisme, Cahaya Insani: Yogyakarta, 2018.
Obsatar Sinaga, Prayitno Ramelan, Ian Montratama, Terorisme Kanan Indonesia, Dinamika dan Penanggulangannya, Elex Media komputindo: Jakarta: 2018.

Peter Mahmud Marzuki, Penelitian Hukum Edisi Revisi, Prenada Media Group: Jakarta, 2017.

Satria, Anatomi Hukum Pidana Khusus, UII Press: Yogyakarta, 2014.

Solahudin, Jihadisme di Indonesia, Komunitas Bambu: Jakarta: 2011.

Syaiful Arif, Islam Pancasila dan Deradikalisasi, Meneguhkan Nilai Keindonesiaan, PT Elex Media Komputindo: Jakarta, 2018.

Widodo, Memerangi Cyber crime, KarakteristikMotivasi, dan Strategi Penanganannya dalam Perspketif Kriminolog, Aswaja Pressindo: Yogyakarta 2013.

Zuly Qodir, Radikalisasi Agama di Indonesia, Pustaka Pelajar: Yogyakarta: 2014. 


\section{Hasil Penelitian}

Sunardi, Klausula Attentat Dalam

Kaitannya Dengan Ekstradisi Pelaku

Tindak Pidana Terorisme, Disertasi,

Program Pascasarjana Fakultas

Hukum Universitas Brawijaya,

Malang, 2009.

\section{Jurnal}

Hery Firmansyah, Upaya Penanggulangan

Tindak Pidana Terorisme di Indonesia, Mimbar Hukum,23 (2011).

\section{Internet}

"BNPT sebut kontra ideologi efektif tanggulangi ancaman terorisme https://m.wartaekonomi.co.id,

"BNPT gandeng kyai seluruh jember untuk cegah radikalisasi, https://regional.kompas.com,

"Skenario kontra narasi untuk mencegah teror", http://www.neraca.co.id,

www.kbbi.web.id,

\section{BIODATA SINGKAT PENULIS}

Dian Eko Timuriyono adalah Inspektur Dua dengan Jabatan KBO Sat Intelkam Polres Jember. Menyelesaikan pendidikan Sarjana Hukum di Fakultas Hukum Universitas Islam Jember dan Magister Hukum di Universitas Jember. 